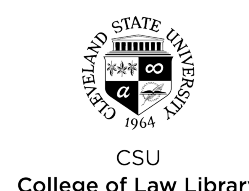

Cleveland State University

College of Law Library

\title{
EngagedScholarship@CSU
}

$1-15-2016$

\section{Political Economy, Capitalism and the Rule of Law}

David R. Barnhizer

Cleveland State University, d.barnhizer@csuohio.edu

Daniel D. Barnhizer

Michigan State University College of Law

Follow this and additional works at: https://engagedscholarship.csuohio.edu/fac_articles

Part of the Law Commons

How does access to this work benefit you? Let us know!

\section{Repository Citation}

Barnhizer, David R. and Barnhizer, Daniel D., "Political Economy, Capitalism and the Rule of Law" (2016). Law Faculty Articles and Essays. 821.

https://engagedscholarship.csuohio.edu/fac_articles/821

This Article is brought to you for free and open access by the Faculty Scholarship at EngagedScholarship@CSU. It has been accepted for inclusion in Law Faculty Articles and Essays by an authorized administrator of EngagedScholarship@CSU. For more information, please contact research.services@law.csuohio.edu. 


\section{CLEVELAND-MARSHALL COLLEGE OF LAW}

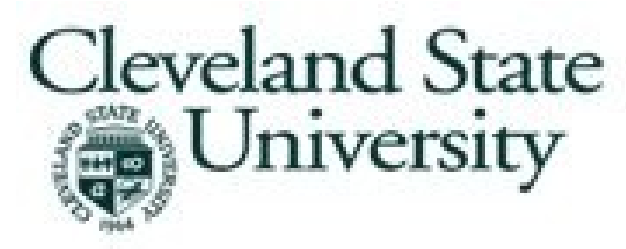

Research Paper 16-292

January 2016

\section{Political Economy, Capitalism and the Rule of Law \\ by}

\section{David Barnhizer}

Professor Emeritus of Law, Cleveland-Marshall College of Law

and

Daniel Barnhizer

Professor of Law, Michigan State University College of Law

Working Paper

This paper can be downloaded without charge from

the Social Science Research Network electronic library:

http://ssrn.com/abstract=2716372 


\title{
Political Economy, Capitalism and the Rule of Law \\ David Barnhizer and Daniel Barnhizer
}

\begin{abstract}
Contents
Political Economy and the Rule of Law

The Rule of Law and Its "Deep" Belief System Is Challenged by a Host of New and Powerful "Private" Institutions Committed Solely to Their Own Agendas

Brief Outline of the Major Tenets of the Austrian Method of Economic Analysis

SESSION 1: WHAT IS THE RULE OF LAW AND WHY DOES IT MATTER?

SESSION \# 2: WHAT IS DEVELOPMENT?

SESSION \# 3: THE INSTITUTIONAL APPROACH TO DEVELOPMENT

SESSION \# 4: INTRODUCTION TO CONSTITUTIONAL ECONOMICS,

SESSION 5: THE RULE OF LAW AND ECONOMIC GROWTH IN AMERICAN HISTORY

SESSION 6: PRESERVING CONSTITUTIONAL GOVERNMENT: CONSTITUTIONS IN TIMES OF CRISIS
\end{abstract}

SESSION 7: THE RULE OF LAW AND CRONYISM

The Rule of Law as a Fragile and Ephemeral Ideal

The Rule of Law and the Growth of an Incommensurable Rigidity

The "Truth" of the Rule of Law

The Will of the Political Mass and the Re-Engineering of Individuals

Institutions, Orthodoxies and Organizations

Liberal Democracy v. Cultural Democracy

The Power Pluralism of Single-Cause, Single-Interest Groups 


\section{Political Economy and the Rule of Law}

There are several purposes for this analysis. We want to begin by expressing our appreciation to George Mason University for pulling together a workshop on political economy and the Rule of Law that we were able to participate in during early December 2015. The workshop drew presenters from the discipline of political economy whose insights enriched the participants' perspectives in relation to understanding the complex connections between economic analysis and behavior in coordination with the nature and function of the unique version of the Rule of Law operating in America and Western democratic societies.

There is a fundamental symbiotic relationship between a society's form of economic activity and the nature of the Rule of Law system that supports, facilitates and limits that activity. At the heart of the interactive relationship is a dynamic by which power is created, allocated, denied and adapted over time. The core fact is that of change and transformation of the nature of power and the identities of those who control it. Nothing in such a system remains static and, unlike other systems, it is the natural intent of the system to reward its participants for creative contributions that sustain and advance its dynamism. The Rule of Law in the Western democracies represents the collection of deeper cultural values within which the dynamic activity takes place and operates as a facilitator, governor and definer of the economic activity by which power is distributed and social goods created and shared.

Joseph Schumpeter once explained: "The capitalist process not only destroys its own institutional framework but it also creates the conditions for another. Destruction may not be the right word after all. Perhaps I should have spoken of transformation." 1 This point is raised because it seems quite obvious that we are at a point of transformation and that, while we can understand that fact without question, we still have no clear idea about the full nature, scale, elements, timing, costs, benefits or consequences of that transformation. It is much like Nikolai Kondratiev observed in accordance with his description of "Kondratiev Waves" that periodically affect the form and structure of an economic system. Although there are challenges to the existence of the periodic "waves" in terms of their specific timing there is no real dispute that capitalist societies undergo fundamental transformations. We are experiencing such a transformation at this point, it has been unfolding for more than a decade and is still not finished. A key aspect of Kondratiev's "Wave" concept is that the system does not simply change in degree as a linear phenomenon but shifts "in kind" and takes on new characteristics while discarding some of those associated with its previous form. ${ }^{2}$

Given what we are saying about the close connection between economic activity and the Rule of Law within which that activity takes place we assert that it is difficult if not

\footnotetext{
1 J. Schumpeter, Capitalism, Socialism and Democracy 162 (1950).

2 See, Alexander Alvazov and Andrey Kobyakov, "Nikolai Kondratiev's "Lon Wave": The Mirror of the Global Economic Crisis", October 25, 2008. http://www.globalresearch.ca/nikolai-kondratiev-s-long-wave-the-mirror-of-theglobal-economic-crisis/11161.
} 
impossible to understand either sub-system in isolation from the other. It is also inevitable that the Rule of Law element, while creating a framework within which economic activity occurs is largely controlled by that economic sphere. We are fully committed to the Western version of the Rule of Law and consider the form that economic activity takes in Western democracies as a vital "cause-and-effect" element of that system. ${ }^{3}$ In this brief analysis we will try to make these considerations obvious and provide some context and support for the assertion. At the beginning we want to make plain that this exercise is not empirical or evidential. It is not perfectly rational or demonstrable through use of pure logic or Reason. Nor do we want to conceal or deny that in some ways the insights or claims offered are not partial, presumptive, based on principles that cannot be proven, hypocritical, or representative of ideals rather than "truths".

Political systems, like religious faith, are belief systems far more than ones of pure logic. In part they are based on assumptions, faith, ideals, "deep" beliefs and even illogic. This is the nature of human societies and operating systems and we make this assertion without hesitation or embarrassment. Following this, we also suggest that once we move past theoretical and abstract systems the context created by the conjunction of the Western version of the Rule of Law and the economic system made possible by and generative of that version of the Rule of Law is a unique system that with all its numerous deficiencies offer considerably more to the more than one billion people of North America and Western Europe than any other historical system and those that populate the remainder of the world at this time-systems committed to a more or less static condition of power and wealth allocation that restricts the opportunities and development of their people and the protection of power elites and castes that control their populaces by denying them the chance to fully participate in their societies.

The following analysis attempts several things. One is to offer an overview of what we saw as the main points of the workshop presentations. We don't pretend to have captured all of the most vital insights but have tried to outline the main issues. The other element in the analysis involves some of ouyr own thinking on the conjunction of Rule of Law and political economy issues. In that regard elements are intertwined in relation to how legal, political, business and economic issues form a system considerably beyond stand alone disciplinary elements studied by academics out of context with the other parts of what is an integrated and dynamic system.

There were numerous important points made during the workshop, many of which are highlighted in the text that follows offering specific bullet points from the individual presentations. Among the most important was Michael Munger's insight that when we are seeking to implement effective social reforms that we have to take the political and power realities of where a system is and build those considerations into our strategies rather than simply attempt to create and implement "ideal" actions that may appear fine in theory but will not work in practice because they dictate unacceptable and threatening changes to those already in power. Assuming we are not attempting violent overthrow of a regime existing allocations of power must be taken into account in our pursuit of positive

3 On such issues see David Barnhizer \& Daniel Barnhizer, Hypocrisy and Myth: The Hidden Order of the Rule of Law (2009). 
adaptation because those in possession of significant shares of power have the ability to block changes that have the potential to produce highly negative effects on what they perceive to be their interests.

Munger therefore warns that in seeking any sweeping change you have to "begin from where you are to have a chance of ending up anywhere close to where you want and need to go." He offered the saga of political change in post-Allende Chile as an example. We could easily add the issue of changing from a fossil fuel-based energy system to one of "clean" energy capable of slowing the intensification of what many consider to be manmade climate change with devastating implications for human societies. Without going into detail, the fact is that enormous power, leverage and privilege exist in the hands of those who benefit from the existing energy system. Millions of jobs depend on that system as well as the enormous wealth possessed by massive energy companies and nations who depend on the continuation of "business as usual" regardless of prophecies about climate change and ecological disaster. David pursued such matters in an article published in the Georgetown International Environmental Law Review, “Waking from Sustainability's "Impossible Dream”: The Decisionmaking Realities of Business and Government”. 4

Even at this moment we see an "old regime" trying to block the transition to a "new regime" in Venezuela where the nation's Supreme Court, whose members were appointed by the Chavez regime, is attempting to block a critical number of newly elected members of Venezuela's congress from being sworn in and seated. The numbers involved are sufficient to deny the new parliament from having a veto-proof edge by which it could reverse some of the fundamental elements of “Chavismo".

One lesson that was present throughout the analyses, even if often an implied subtext, is that economics is opportunity, power and the creator of social well-being, not an end in itself but a means. We don't create wealth and opportunity so that people can live licentious or opulent lifestyles or engage in "jet-setting". We facilitate economic activity so that opportunities are created for a diverse and extensive citizenry and that societies have the ability to nurture and sustain members of their communities with the aim of allowing the highest level of human evolution-recognizing that a basic level of resources and a societal openness to change and adaptation based on merit and development lie at the core of our social mission. The dynamics of our economic systems are therefore one of the core methodologies through which we try to ensure that the community operates well.

It is also important to note at this point that the pursuit of material wealth, the "almighty dollar", is not what is meant in describing the critical nature of economics and wealth creation. Material wealth is a vital manifestation of "wellness" on many levels because to provide the opportunities required for a diverse populace a significant level of resources is essential. But financial wealth accumulation for a narrow tier of individuals is only one element and it is a secondary consequence rather than a primary aim. If it is taken to extremes and the laws created ostensibly to function properly within the Rule of Law

\footnotetext{
4 David Barnhizer, "Waking from Sustainability's "Impossible Dream": The Decisionmaking Realities of Business and Government”, 18 Georgetown International Environmental L. Rev. 595 (2006).
} 
framework are abused and taken outside the purpose of the Rule of Law as a system of "deep" principle then there has been an unacceptable "disconnect" between the legitimacy of the law and the Rule of Law in which laws have become nothing more than specific devices of power and manipulation and have lost their connection with the systemic "soul" provided by the Rule of Law. Randall Holcombe touched on this "disconnect" when he addressed the issue of "crony capitalism" and its denigration of the principles of Liberty and the Rule of Law.

Power, status, happiness, security, personal growth, fairness and justice are other elements of a political community that can be made of critical significance to a culture and that to a significant degree depending on the dynamics and complexity of a specific culture are made possible by economic systems or undermined. Along with the above considerations, security and predictability are critical values because some people are creators and artists while most people want structure, security, a decent life, respect, family and a sense of belonging and meaning. Some seek to create "masterpieces" for the ages. Others take pride in day-to-day work and production and are satisfied if they feel they have made a contribution that sustained their family or local community.

\section{The Rule of Law and Its "Deep" Belief System Is Challenged by a Host of New and Powerful "Private" Institutions Committed Solely to Their Own Agendas}

The connection between the Rule of Law as existing in America and Western Europe and economics is that the Rule of Law is the belief system underlying the integrity of the public and private institutions by which society is ordered and operates. It is also the quasiinchoate creed based on the values and principles that allow the system to operate and evolve. The fact is that the Rule of Law is not a fully rational and concrete system but a relatively loose bundle of underlying themes that sustain the operation of specific laws and specific institutions whether those institutions are public, quasi-public, private or quasiprivate or customary in nature.

Basically, any system or sub-system that is allowed by the operating rules of our culture is a kind of "institution" because by being allowed a system is endowed with powers that allow the resulting institution to impose costs and benefits within the dynamic community. At this time we are undergoing an important transformation of institutions and what are thought of as institutions given the expansion in communications and data-gathering capabilities produced by computers and the Internet.

Here we are saying that the nature of an institution relates to its ability to mobilize and focus power on a scale relevant to its operational context. This means that with the new organizational and communications capabilities, supposedly "private" actors can become "institutions" because they possess the ability to influence action and policy in fundamental ways and on a significant scale. Consider Facebook, Google, the National Rifle Association, the National Education Association, environmental coalitions, the fossil fuel energy lobby, LGBT organizers, the Wall Street financial powers, and many more tremendously wellresourced and powerful institutions. It is absurd to consider these actors as simply "private" entities because they wield enormous power and influence over our political 
decision-makers. As such they also are capable of "bending" rules and their enforcement in ways that serve their own interests and represent powerful institutions operating on a scale never contemplated by those who created our Constitutional government.

The nature of the "power elite" is in the process of changing. Traditional powers may be able to hold onto a significant part of their shares but communications technologies have done something that has radically altered the political landscape. Unfortunately it has also contributed to the social fragmentation that is endangering the traditions of our Rule of Law. The idea of power elites and the return on power takes various forms, and in the new information and communication society where the power of mobilization, communication, "press" coverage and media is rendered cost free or incredibly inexpensive the rules of the "power elite" "game" have changed in fundamental ways.

Compare Internet and software capabilities and exposure and conspiracy claims and hacking, etc. with what has existed previously in which information was fully controlled or localized then we can see we have entered a different social context in which traditional "power" is threatened and vulnerable. But the traditional institutions of power are evolving their own responsive strategies as in China's strategy of controlling political discourse on the Internet in efforts to try to dominate discourse and control or repress others power. ${ }^{5}$ This is creating new institutions that dislocate traditional power nodes and allow the most powerful institutions to remain outside direct control and accountability in a globalized state.

Todd Zywicki offered the view that the Rule of Law operates as a restraint on government and we obviously agree with that view. But we would also argue that it is actually a restraint on power and the institutions by which power is exercised to benefit interest groups. This means that in a system of the kind that is rapidly expanding in the US, the lines between "government" and "private activity" have become blurred with numerous overlaps. In our situation it is unclear what actually is "government" and what is "private". If significant power has been transferred to private institutions or new versions and methods of acquiring and exercising power created by private organizations and interest groups we suggest that we need to determine whether based on that power we should consider the relationship between such theoretically "non-governmental" interests and the Rule of Law's legitimacy or rigidly restrict ourselves to formalistic definitions that say "government" is "government" and end the inquiry at that point.

After reading the above paragraph Zywicki made the following comments and clarifications with which we agree fully.

"I think my views are more congenial to your insights than you might think and it has to do with my references to Oakeshott and the larger sense of Hayek's of the rule of law essentially being about governance to a system of rules, that need not necessarily be legal rules (this is the thrust of Law,

\footnotetext{
5 "China says Communist Party to be 'strongest voice in cyberspace"',

http://news.yahoo.com/china-says-communist-party-strongest-voice-cyberspace-005510561.html.
} 
Legislation, and Liberty I take it). ${ }^{6}$ Now let me emphasize that my impression is that how I think about this is somewhat idiosyncratic. But I take Hayek (and Oakeshott) ${ }^{7}$ to be saying that what we really need is a system of rules that will enable each of us to predict how others will act and to maximize the coordination of our plans. So those rules could be legal rules and often those are the most important. But they could also include cultural rules or other institutions so long as following those rules promotes individual coordination and private ordering.

I hadn't thought about it the way that you say it above, but I think it is certainly consistent with that larger view--if private institutions are able to essentially "create" new rules that actually govern behavior, then I personally would include those within thinking about the rule of law as a system of institutions. And to the extent that they are centralized rulemakers in some sense, one would predict that they would be subject to the same potential problems of capture and the like.

As an analogy (and I think you are saying something deeper and more profound than this), consider the ALI Restatement and NCCUSL uniform laws. There is this body of literature that finds that originally those bodies were to some extent insulated from lobbying, simply because interest groups didn't really know to lobby them (of course, they were a playing field for the particular ideological agendas of the members, but not interest groups). Once interest groups recognized that is where the real action is and that state legislatures more or less just rubber-stamp those proposals and pass them into law, the interest groups started lobbying those "private legislatures" to influence their outputs. Which is what you would expect (and which is one reason why as a good Hayekian I prefer decentralized common law evolution instead of centralized restatement-style projects)." ${ }^{8}$

Our conclusion is that if we do not develop an interpretation of the applicability of the Rule of Law to powerful private interests that nonetheless possess resources and leverage equal to or superior to many governments then the Rule of Law has been rendered irrelevant and exists mainly as a decaying rhetorical artifice. Such an interpretation is consistent with Randy Holcombe's assault on "crony capitalism" in which key government actors have been taken over by private interests and caused to allocate illegitimate benefits to those interests or protect them against fair attacks on their systemic abuses.

Underlying all this is the interplay between the person as individual and the individual as a contributing part of the community. Even here there is significant tension because most people simply want to "be part of something" larger than themselves or something that

\footnotetext{
${ }^{6}$ See, Friedrich Hayek, Law, Legislation and Liberty (1973).

${ }^{7}$ See, e.g., Michael Oakeshott, The Voice of Liberal Learning (1989); Oakeshott, Experience and Its Modes (1933); Oakeshott, On Human Conduct (1975).

${ }^{8}$ E-Mail comments from Todd Zywicki to David Barnhizer, January 13, 2016.
} 
takes care of them and offers a defined role and responsibility, confers rewards and status, and provides a comforting structure and predictability to their lives. The tension is created because in some situations "the" community is defined as "their" community and develops into a political orthodoxy seeking to gain and consolidate power for itself and its members. Alternative "communities" and people who insist on being fully developed individuals in the classic Existentialist sense are seen as threats or as misguided creatures who need to "get with the program".

\section{Brief Outline of the Major Tenets of the Austrian Method of Economic Analysis}

Prior to summarizing the offerings of the workshop presenters it can be useful to set forth a listing attributed to Fritz Machlup of the main tenets of the Austrian school of economic analysis. The list may be from Wikipedia but for our purposes serves the purpose of understanding the approach and assumptions of the Austrian approach to economic analysis, the emphasis on individual choice and liberty, the role of government, and the functions of the collective action of groups and other private actors. ${ }^{9}$

“(1) Methodological Individualism: In the explanation of economic phenomena we have to go back to the actions (or inaction) of individuals; groups or "collectives" cannot act except through the actions of individual members.

(2) Methodological Subjectivism: In the explanation of economic phenomena we have to go back to judgments and choices made by individuals on the basis of whatever knowledge they have or believe to have and whatever expectations they entertain regarding external developments and especially the perceived consequences of their own intended actions.

(3) Tastes and Preferences: Subjective valuations of goods and services determine the demand for them so that their prices are influenced by (actual and potential) consumers.

(4) Opportunity Costs: The costs with which producers and other economic actors calculate reflect the alternative opportunities that must be foregone; as productive services are employed for one purpose, all alternative uses have to be sacrificed.

(5) Marginalism: In all economic designs, the values, costs, revenues, productivity, etc., are determined by the significance of the last unit added to or subtracted from the total.

(6) Time Structure of Production and Consumption: Decisions to save reflect "time preferences" regarding consumption in the immediate, distant, or indefinite future, and investments are made in view of larger outputs expected to be obtained if more time-taking production processes are undertaken.

Two important tenets held by the Misesian branch of Austrian economics may also be added to the list:

(7) Consumer Sovereignty: The influence consumers have on the effective demand for goods and services and, through the prices which result in free competitive markets, on

\footnotetext{
${ }^{9}$ https://en.wikipedia.org/wiki/Austrian_School\#cite_note-Machlup_Mises-22.
} 
the production plans of producers and investors, is not merely a hard fact but also an important objective, attainable only by complete avoidance of governmental interference with the markets and of restrictions on the freedom of sellers and buyers to follow their own judgment regarding quantities, qualities, and prices of products and services.

(8) Political Individualism: Only when individuals are given full economic freedom will it be possible to secure political and moral freedom. Restrictions on economic freedom lead, sooner or later, to an extension of the coercive activities of the state into the political domain, undermining and eventually destroying the essential individual liberties which the capitalistic societies were able to attain in the nineteenth century." ${ }^{10}$

\section{SESSION 1: WHAT IS THE RULE OF LAW AND WHY DOES IT MATTER?}

\section{Todd Zywicki, Executive Director, Law \& Economics Center and Professor of Law, George Mason University}

- The primary emphasis is on New Institutional Economics and the Austrian School of economic analysis represented by Hayek. ["New institutional economics (NIE) is an economic perspective that attempts to extend economics by focusing on the social and legal norms and rules (which are institutions) that underlie economic activity and with analysis beyond earlier institutional economics and neoclassical economics." ${ }^{11}$

- Although we often use the term the "Rule of Law" it is actually shorthand for a variety of other topics.

- Here we are speaking of the strong relationship between Economics in relation to actual individual and institutional behavior and the Rule of Law.

- The Rule of Law operates as a facilitator, structure, and dynamic stimulus for our economic system and society.

- An interesting question is how was the Rule of Law created and why does it matter? Where does the Rule of Law come from? Some trace its origins to Magna Carta's deal between the king and feudal barons but that may be overstated.

- One of its most vital characteristics and functions is that the Rule of Law acts as a restraint on government and as such supports private action in the form of individual decisions, group action and institutions.

\footnotetext{
10 https://en.wikipedia.org/wiki/Fritz_Machlup.

11 https://www.google.com/search?q=New+Institutional+Economicsd\&btnG=Google+Search\&gws_rd=ssl.
} 
- An important aspect of the connection between economic activity and the Rule of Law is that it offers the ability for investors and economic innovators to predict how others will act.

- The result is that legal rules provide input to the economic decision-making process.

- The Rule of Law is not "just" rules of law. It is a "purpose independent" system in which rules are ones that allow people to make choices within a shared framework that allows them to pursue their own goals. In this regard consider Adam Smith's idea of the "invisible hand" where the sum of billions of individual decisions made by a population's actors according to their own ends result in a rational and positive outcome.

- A byproduct of the Rule of Law is that nations are wealthier or "better off" on a variety of levels but that is an effect rather than a goal. Here we can think of Aristotle's idea of seeking to create the highest development of our individual "selves" with the result that the sum of the total mass of invisible decisions by members of a populace results in the most well off and enlightened communities.

- Some indicate that the political fragmentation of Europe several centuries ago led to competition among princes. This created the ability of merchants to move if they considered themselves oppressed, or perhaps if they had a significantly better offer. An interesting parallel today is that globalization means that corporations can move their legal tax headquarters or financial centers without shifting the productive reality of their operations. Globalization means that many corporations and production activity and trade are outside the control of individual nations, even the biggest ones such as the US. This can force the modern "sovereign" to "behave". It also creates a power imbalance between major economic actors and local governments and labor forces that may "offend" during the stage of an economic cycle in which new capital and relocation decisions are made and find themselves left behind.

- Does the institutional structure create the conditions of THE Rule of Law and are there multiple variations of the Rule of Law in the US, Canada and Western Europe?

- The idea of the Rule of Law is that there is a law above the state. It supports and constrains government. But of late we have to consider the emerging allocations of power, the shape and location of economic development and the effects of "crony" capitalism as narrow niches of private actors increasingly come to influence and even control the decision-making of governmental authorities.

- How do people make decisions to do all this "stuff" that we place under the heading of economic behavior? Each of us is trying to do our "own thing". Realistically, each of us is trying to survive and benefit from our choices. 
- The formalistic "Appearance" of the Rule of Law is important and if it becomes "tattered" and disrespected it can loose its ability to shape and contain economic and political decision-making to the extent we are left only with self-centered and unproductive rent-seeking unconcerned with the welfare of the overall community.

- In numerous countries, including to some extent in Western democracies ostensibly operating pursuant to the Rule of Law, there is a formal economy and a black market or "off-the-books" informal economy. This involves methods of "hiding assets and earnings" in non-Rule of Law situations to avoid having one's resources and profits taken through corruption, incessant bribery, and protection rackets in order to stay in business.

- We are in an era witnessing the decline of the Rule of Law and the rise of crony capitalism. Financial crises lead to the unraveling of the Rule of Law and the rise of discretionary government that takes emergency measures aimed at reversing or mitigating the crisis. The problem is that in a crisis extraordinary measures are often thought necessary and the risk is that those steps invoke powers beyond constitutional governmental authority and expands the scope of official discretion. Discretionary government creates too many opportunities for manipulation and the development of a bias for one approach or interest group and against another.

- One question is whether we can "put the genie back in the bottle" once discretionary government and its actors have tasted the expanded scope of their powers? The answer seems to be "No". Sarbanes/Oxley (SOX), for example, is a terrible example of crisis decision-making following the Enron debacle. Done in a crisis context, it was an incredibly expensive, vague law in search of targets. Many companies, but especially smaller companies, were forced to incur significant expenses for staff and external services in an effort to comply with the law's anticipated but unclear rules.

- The Rule of Law is not an instrument of fast action and the desire or need to take fast action in an emergency situation can lead to a relaxing of the Rule of Law from which it is difficult to recover.

- A specific example of crony capitalism and largely unfettered governmental discretion is that politically connected donors received a high proportion of TARP funds. And some of them didn't even need them.

- In theory we may have dispensed with the "Divine Right of Kings" but when Congress or an Imperial Presidency become the "King" you have sort of a "Divine Right of Senators and Representatives" or "Divine Right of President" that makes it extremely difficult to reinstate the integrity of a strong Rule of Law once it has been "relaxed" to deal with a crisis or perceived emergency. The problem is that Congress, presidents, lawyers and bureaucrats like their new power. A lack of specificity accompanied by linguistic vagueness allows for too much discretion in interpretation and application. Dodd/Frank's "Too Big to Fail” approach for SIFI's 
(Systemically Important Financial Institutions) is an example of this phenomenon. There has been a disproportionate impact by statutes and regulations on smaller financial and business institutions as seen with both Sarbanes/Oxley and Dodd/Frank. This increases the system's vulnerability and weakens the Rule of Law because the momentum generated is toward larger and larger institutions that are non-accountable for irrational risk taking because they know they will be bailed out by government-and also stifles innovation and entrepreneurial activity by individuals and smaller institutions who cannot compete with the scale and repressive behavior on the institutional goliaths that dominate industries.

- There is a "Moral Hazard" involved in the grant of discretionary power. If government gains the power to intervene people expect it will do so and help "fix" a situation. But accountability and restraint are almost totally lacking even though such considerations are considered integral to the legitimacy of the Rule of Law.

\section{SESSION \# 2: WHAT IS DEVELOPMENT?}

\section{Christopher Coyne, FA Harper Professor of Economics, George Mason University and Associate Director, FA Hayek Program for Advanced Study in Philosophy, Politics, and Economics, George Mason University.}

Development Economics, a discipline operating in contexts where the Rule of Law as we understand it either does not exist at all or in highly imperfect and unpredictable forms offers a useful look at what must exist in a high-functioning political economy located within a legitimate Rule of Law system.

- Development Economics involves using scarce resources to generate wealth. This can include non-material and material wealth, subsistence, substantial, building a middle class, enhancing a system's charity capability, improving government, business climate, etc.

- Most development economists focus only on one measure of wealth and progress such as GDP.

- The foundations of development economics include: 1 . Study of human behavior where choice and options exist, 2. Choice based on scarcity of available resources, 3 . The assumption that competition cannot be avoided versus a narrow perspective that competition is bad.

- There are different abilities relating to the power to compete effectively. This includes the power to do things and the power to prevent others from doing things that affect you or that you don't like. 
- We need to identify the institutions that are capable of shaping our choices.

- Opportunity costs are where you have to choose and in doing so surrender the value of having taken other options. But there is a subjectivity to what you give up because since it doesn't actually exist other than as a potentiality because you chose something else, you have a very hard time assigning it a realistic value or any value.

- Two key issues for development include: 1 . Moving from subsistence to exchange economies. This involves issues of the division of labor and value added activities, 2. Mechanisms and processes for choice in terms of discovery of options and the ability to make choices based on an economic calculation.

1. The idea of the division of labor is when an economy is able to have its actors specializing in a task or role with other people involving trade offs of functions and between functions.

2. This is limited by the extent of the trading market (intensity, scope, diversity and distance).

3. Advanced material production goes beyond the local context into the realm of anonymous exchange dealing with people you don't know but must trust or hedge against. Part of this is accountability pressures generated by a localized trading market in which people must deal with each other continually or frequently and reputation matters versus an extended anonymous trading market where accountability pressures tend to be less.

4. But we need to identify in a specific setting how people coordinate with others and know what is available.

5. In economic systems we tend to think of markets as satisfying demand but there is also Galbraith's idea of creation of demand as a key function of business. You don't wait for people to come to you but attempt to create demand. Much of advertising involves this approach.

6. What can be called "Commodity Output" v. "Value-added" output represent distinct approaches. Rather than simply delivering commodities on a local or basic level, economies grow in wealth and sophistication by multiplying the value of a commodity through transforming elements of its composition into a variety of uses. Oil offers an easy example given that in the refining process the commodity of oil is variably transformed into a large number of products for which significantly increased prices are obtained.

7. To continue the "value added" discussion, among the many products obtained from the commodity of oil are: Plastics, Ink, Paint, Shoe Polish, Nylons, Roof shingles, Novelty Candy, Cosmetics, Candles, Vaseline, Bug Killer, Ammonia, Tires, Asphalt, Crayons, Paper cups, and Wax paper.

8. "Capabilities" approach is a fuller definition of development.

9. Coyne's "development" has a general community benefit morality bias.

10. The ability to bring a product (or service) to market is vital for development.

11. Coyne says everyone can be an entrepreneur but the fact is that is not true for a variety of reasons. This is particularly so if we differentiate a "successful" 
entrepreneur from one who has good or great ideas but can't take them anywhere. So what do we mean by "entrepreneur"?

Characteristics of the market process:

1. Spontaneous order-purposive human interaction by not design v. designed order.

2. "Ends" independent.

3. Open-ended discovery process.

- But many ruling elites in developing countries don't want a middle class because it questions and challenges and seeks fair treatment and rights.

- Modern economic development between countries equals central planning. There is a negativity of "experts".

- Why certain societies “develop” and others can't or won't.

- The "friction" of the existing power system is one in which a privileged orthodoxy controls the institutions and mindsets and access.

- This is often done in the name of "protecting the people".

\section{SESSION \# 3: THE INSTITUTIONAL APPROACH TO DEVELOPMENT}

\section{Christopher Coyne}

Economic calculation is primarily an individualistic concept.

1. What are "institutions"? They can be formal and informal, codified and private or public. Institutions set the "rules of the game".

2. Informal institutions represent strong social norms and we need to think about: a. the disintegration of social norms and b. the diversity of social norms. Along with this we might consider the relative strengths and power of individual normative systems.

3. Institutions matter because they create the rules that produce potential payoffs, not only financial but other kinds of rewards people desire.

4. Which "institutions" matter most? In the context of economics and the Rule of Law the institution of property rights is important because it allows economic calculation and the ability of private owners to benefit by using resources that benefit others and in doing so they can maximize benefits to themselves in the form of profit. The assumption here is that owners have a strong incentive to care for, invest in and manage their property while avoiding harm to others when operating within a predictable and stable meta-environment. Of course we have to consider 
the behavior of slum landlords, the phases of investment cycles, changing technologies and market dynamics, and the "cash cow" "milking" of final profit. These behaviors are, however, even though arguably predatory in one sense, predictable behaviors in a stable situation in which the rules are clear and predictable.

- Development requires freedom (consequentialist)

1. To experiment

2. To build relationships

3. To invest in human and physical capital

- Classical Economics has become non-institutional. Markets are imperfect. They will fail. Compare the perfect markets idea of classical economics to that of the superhero. Neither exists.

- Stable and predictable rules about property are crucial. Government confiscation of property is a problem as is gang and corruption activity.

- When human capital can't be transformed into productive activity because locations within countries can't be structured for opportunity-the entrepreneurs leave.

What IS property and the paradox of government.

1. Property rights are crucial for positive economic outcomes and prosperity.

2. A central issue is where government is empowered to protect property rights but ends up controlling those rights excessively. A fundamental question is how can you constrain government's natural drift toward the centralization of power? There is a "collective action" problem.

Arbitrary Government:

1. Picks winners and losers.

2. Undermines desirable features of private property and markets. [bribery/corruption/crony capitalism/rent-seeking]

3. The concept of the Rule of Law is crucial for addressing the paradox of government.

4. Open to the whims of the regulator.

5. Unhealthy relationships are created between "public/private" actors that form informal partnerships.

6. We can't have costless regulation.

Rule of Law characteristics:

1. Non-arbitrary

2. General rules that apply to everyone 
3. No one is above the law

4. Power is bound by constitutional procedures

5. Predictability - rules known in advance and followed

6. Transparency and right to defense and notice of charges based on clear rules and responsibilities.

- The pursuit of "Human Flourishing" involves the opportunity to work to become the person we desire to become, with all individuals imbued with freedom to decide and act as long as the action does not violate the property rights of another individual.

- The existence of a "private sphere" (privacy) free from government intervention.

- Personal development can overlap with the economic sphere.

- People and groups are often marginalized due to absence of property rights and lack of the Rule of Law versus the Rule of arbitrary and discretionary power.

- Empirical Evidence and the challenge of "Deep Culture".

\section{SESSION \# 4: INTRODUCTION TO CONSTITUTIONAL ECONOMICS}

\section{Michael Munger, Professor, Department of Political Science, Professor, Departments of Economics and Public Policy, Duke University}

- Constitutional Political Economy [CPE] is an offshoot of Public Choice doctrine or the use of economics to understand the choices to be taken in politics and political economy. ${ }^{12}$

- The moral philosophy of exchange. To what extent is exchange "truly voluntary"?

- James Buchanan's view is adopted. CPE is about choosing among alternatives in rules and rule regimes. "If rules influence outcomes and if some outcomes are "better" than others, it follows that to the extent that rules can be chosen, the study and analysis of comparative rules and institutions become proper objects of our attention. Without an understanding of how the individuals who make up a social order interact, and how different sets of rules affect these interactions, it is impossible for participants to make informed changes in existing rules or even to behave prudently with respect to the preservation of those rules that have proved essential to the tolerably efficient functioning of the society as such."13

12 For background, see, Geoffrey Brennan and James M. Buchanan, The Reason of Rules: Constitutional Political Economy (2000).

http://www.econlib.org/library/Buchanan/buchCv10c1.html\#Ch.\%201,\%20The\%20Constitutional\%20Imperative.

13 Reason of Rules, id. 
- Importance of understanding what "Public Good" actually is.

- A community without a "politeia" is just a bunch of people, not a community at all. The politeia is the soul of the polis. This is a Golden Rule "do unto others" variant.

- CPE asks "How can people solve collective action problems where markets, left to themselves, cannot solve the problem. There is a need for a threat of coercion [best left known but implied].

- Non-market exchanges, actual consent (social contract) does not happen. [Voluntary associations and clubs fill gaps in government capability.]

- Game theory is key to CPE. Humans are rule followers [but some are rule breakers and free riders and predators].

- SIFI-Systemically Important Financial Institutions [externally more important than fiscal discipline]. This situation is one in which the financial institutions have developed such an operational and interlinked scale that as we saw in 2008 they are capable of "crashing" the system due to actions that may have been rational from the perspective of the institutions and individuals directly benefitting from highly risky actions but that subject the overall financial, governmental, employment and production systems to significant negative consequences. The enormous scale and interwoven nature of the system creates risks far beyond matters of individual economic decision-making but the unpleasant fact is that even though we are now completely aware of such risks we have actually increased the likelihood of such behavior on the part of financial institutions because under Dodd/Frank they are fully aware that the US federal government will not allow them to fail. This is a complete perversion of the principles of the Rule of Law because the decisionmakers in such situations profit from good and bad decisions and as in the 2008 "meltdown" they are not held accountable for their actions because the individuals who take the actions are insulated by the sheer scale of the institution within which they are acting.

- Politics as Constituted Cooperative Action

1. Choosing in groups based on rules agreed on in advance

2. Selfishness v. teamwork tension

3. Groups often work better than government and markets

\title{
SESSION 5: THE RULE OF LAW AND ECONOMIC GROWTH IN AMERICAN HISTORY
}

\author{
Randall G. Holcombe, DeVoe Moore Professor of Economics, Florida State University
}


1. The fundamental principle governing the idea of the American government in 1776 was Liberty. Following John Locke the Founders saw government as the biggest threat to our rights.

2. By contrast, in 2015 the foundational principle of American government is "Democracy" defined simplistically as majority rule. The aim is to carry out the "will of the people". This represents a fundamental change in American ideology.

3. The problem is that the "Will of the Majority" changes over time, is highly influenced by special group interests and propaganda and represents an arbitrary and shifting discretion that undermines the Rule of Law and the Liberty it is intended to protect.

4. There is an arbitrariness at this point represented in the "will of the people". This allows law to be changed easily and this affects fundamental rights and notice and predictability.

5. It produces the idea of the will of the majority but that is so ill-defined and subject to propaganda and manipulation that it has become rights and rules determined by well-connected minorities.

6. The Rule of Law is eroded as our fundamental principle shifted from Liberty to Democracy and then from Democracy to powerful intense political communities pushing special interests.

7. The Founders did not intend a will of the majority democracy.

- The government designed by the Founders was intended to be one-sixth democratic but there were greater states rights and judicial control that was outside direct majority choice. The $17^{\text {th }}$ Amendment changed how Senators were chosen (appointed by state legislatures). There was an insulation of functions from direct vote.

- The Founders saw the Electoral College as a sort of "search committee" and expected that the House of Representatives would end up selecting the President from two or three options submitted by the EC. It was designed to be insulated from direct vote.

- The Electoral College never worked as intended. States moved to popular voting by 1824 .

- 1824 is the year of what is called "The Corrupt Bargain" (Jackson, John Quincy Adams \& Henry Clay). Clay to Adams I'll support you (in House) if you make me Secretary of State. This infuriated Jackson's supporters and in 1828 the Democratic Party formed to get Jackson elected. Whigs then a party formed to counter Democrats.

- The Executive Branch was now subject to Democratic pressures. Jackson said return government to people from political elites. He saw Democrats and democracy as a constraint on governmental power. 
Growth of Veterans' Interests after the Civil War and the Rise of Progressivism and Government as Responsible for the Peoples'Economic Wellbeing.

- The economic vision dispute was whether to pursue a Jeffersonian economy (agrarian base) versus Hamiltonian (industrialism).

- The ideology of Progressivism appeared in the late 1800s. The idea was that government existed not only to protect rights but to look out for the peoples' economic wellbeing. The produced the rise of special interests and a result was an erosion of the Rule of Law as the Progressive Ideology appears.

- Munn v. Illinois (1877) grain elevator monopolies in Illinois.

- Sherman Antitrust Act (1890)

- Clayton Antitrust Act (1914) (price discrimination, exclusivity, tying and anticompetitive behavior].

- US v. IBM (1969) was a Sherman Act claim by the US, with the case dropped in 1982. Was IBM monopolizing the computer industry? It developed the IBM 360 that was the first commercially viable operating system capable of multitasking. IBM had made a huge investment while developing the 360 that could have put it out of business or had serious negatives if the project bombed. It worked and gave IBM a huge market share.

\section{Regime and Institutional Uncertainty or What's Next?}

- Discretion and arbitrariness undermines the integrity and predictability of the Rule of Law. In a situation where laws and regulations are so complex and often vaguely worded that no matter what you do somebody can claim you are violating the law an individual and business actor is uncertain about what to do.

- There was great regime uncertainty in the 1930s. Newly enacted laws created:

1. National Industrial Recovery Act (1933)

2. Agricultural Adjustment Act (1933)

3. Emergency Railroad Transportation Act (1933)

4. Gold Repeal, Executive Order 6102 (1933)

5. Emergency Banking Relief Act (1933)

6. Banking Act of 1933 (Glass/Steagall) [separated investment \& commercial banks and created FDIC]

- Robert Higgs in Crisis and the Leviathan (1987) described how government inevitably ratchets up its powers and never comes all the way back down. 
- One problem is that a highly discretionary government with the power to shift its interpretations and rules as it wishes can create an uncertain climate that affects investment and the operation of productive activity.

- Expanding Regime Uncertainty

1. LBJ's Great Society allegedly represented the triumph of democracy.

2. One problem is that although there was a War on Poverty created, real poverty rates were already falling.

3. Medicare and Medicaid were instituted with a result in greater governmental participation in the private delivery of services, but overall health was improving.

4. Once programs are justified and established they develop constituencies and become popular.

5. But by making the choice to give significant benefits to some, they take from others. This "taking" can be immediate or deferred to future generations, such as with the immense US national debt of $\$ 19$ trillion.

- The Ideology of Democracy Taken to Its Extreme Means that Discretion Replaces the Rule of Law.

1. A majority can compromise individual rights.

2. It introduces cronyism into the system

\section{SESSION 6: PRESERVING CONSTITUTIONAL GOVERNMENT: CONSTITUTIONS IN TIMES OF CRISIS}

\section{Michael C. Munger}

- Accounting for profits is more complex than most economists assume.

- An important question in seeking real change in systems that have historical problems and economic and social distortions that favored one set of interests over others is whether we should respect the distribution of wealth and power that has resulted from the rules about which we are concerned?

- The tension related to the above question about how to deal with what we consider distorted allocations depends on whether one is a "Destinationalist" (utopian) or a "Directionalist" (process oriented) person who is seeking to achieve the best change that can be realistically expected rather than insisting on a complete "fixing" of past conditions.

- People should "own" themselves and no one, including government, should take their property without specific consent. This is at the core of the idea of Liberty 
versus Majority Rule and is a key characteristic of the Rule of Law and its interactive relationship with economics.

- Consistent with the idea that people should "own" themselves and be free to make the choices they consider to be in their interest is that people should also be held responsible for their bad choices and rewarded for the good choices.

- Social Safety Net-Given the total amount the US spends annually on social programs there should be no poverty. But there are still poor people. One problem is that some people make bad choices. Another is that there are massive amounts of governmental actors in poverty and social welfare agencies on the federal and state levels who are inefficient, unproductive and expensive.

- The strategic problem-solving formula we seem to be following uses an intriguing logic. It can be summed up as:

1. There is a problem $X$

2. We need to do something about $\mathrm{X}$

3. $\mathrm{Y}$ is something

4. So we should do $Y$

5. Y didn't work

6. We should do more $Y$

7. Doing Y still didn't work so do more $Y$

8. If you oppose more $\mathrm{Y}$ you "hate" $\mathrm{X}$

- As the "strategic problem-solving formula" set out above suggests, our approach to problem solving at this point is close to Garrett Hardin's classic "Tragedy of the Commons" situation in which a resource in common use by all members of a community such as a commons area used to graze sheep, keeps returning to all who use it until someone goes too far and overloads the commonly utilized field beyond its regenerative capacity. The result is systemic collapse. The converse situation is that when property is held by private owners they pay attention to its capacity and try to ensure that it does not get degraded beyond its sustainable use levels because their livelihood over time and the potential resale value of the property as an asset are critical and cautionary factors.

- It is a serious problem, and one noted by Aristotle in describing the imperfections of democracy as a system of government, that we have come to see the "majority" in a democracy as a "community" and that "community" as a "commons". Unfortunately, we haven't bothered to take into account the problem of the "tragedy" involving overuse of that "commons" and a result is that the system is on the verge of unsustainability or even partly into that condition to the extent it is unlikely that we will be able to avoid the predictable degradation of its productive capacity.

- Collective Action Problems: Examples 
1 England in $18^{\text {th }}$ century

2 US in $19^{\text {th }}$ century

3 Chile in $20^{\text {th }}$ century

4 China at present.

- In Chile according to the new constitution a majority of the Senate and Supreme Court were appointed for life.

- Chile-To go somewhere you have to start from where you actually are. The questions include:

1. Were gains acquired "justly"? There were thousands of desaparecidos whose property and lives were "taken".

2. But you also have to guarantee people a "stream of rent" into the future to obtain "buy in".

3. There have to be credible commitments on which people can rely. This can mean you ignore prior repulsive behavior and even tacitly legitimize it.

A useful read is Robert D. Cooter \& Neil S. Siegel, "Collective Action Federalism: A General Theory of Article I, Section 8", 63 Stanford L. Rev. 115 (2010). They write: "Collective action federalism finds that the limits and expanse of congressional power in Section 8 turn on the difference between individual and collective action by the states. The theory uses this distinction to differentiate interstate commerce from intrastate commerce, not the economic/noneconomic distinction. Our distinction best explains why Congress may not ordinarily use its commerce power to regulate such crimes as assault or gun possession in schools. Collective action federalism also identifies a constitutional "hook" for Congress to regulate multi-state problems of collective action that may not involve commerce: Clause 1 of Section 8 authorizes some forms of regulation of noneconomic harms that spill over state boundaries, such as contagious diseases and certain kinds of environmental pollution."

- Special interests as "trumping" majority control over liberty interests.

- Two Principles:

1. Recognize, not transfer, power.

2. Weakness is strength and strength is weakness.

- Liquidity Crisis v. Solvency Crisis [cash flow v. bankruptcy?]

SESSION 7: THE RULE OF LAW AND CRONYISM

Randall Holcombe 


\section{A THEORY OF CRONYISM (Crony Capitalism)}

Holcombe's preferred term is "Political Capitalism" consistently with Max Weber's interpretation plus Gabriel Kolko's The Triumph of Conservatism (1963) dealing with the Progressive Era's regulation. The idea was "leveling the playing field" as the role of government. This involved breaking monopolies, eliminating bribery, big business trusts and class interests. As to the derivation of the term Holcombe indicates: "The term political capitalism was originally used by Max Weber to describe Roman institutions, but Weber never developed the idea. The term was picked up by Gabriel Kolko in his book, The Triumph of Conservatism, to describe Progressive Era reforms. So while the term was coined by Weber, it was Kolko who developed the ideas along the lines of what I was discussing in my presentation." 14

- Weber saw political capitalism as a conspiracy of the economic and political elites for each of them to maintain or advance their preferred positions in society. He has some sympathies with the concerns of "Occupying Wall Street" protests in 2010. The protesters were criticizing the bailouts of banks, the $1 \%$, foreclosures and the fact that Wall Street got bailed out.

- John Allison, the CEO of BB\&T, was quoted in The Free Market Cure book that he was basically forced to take TARP money even though his bank was solvent. They didn't want some banks to look good and others bad so they wanted all the banks to take the money.

- Ayn Rand in Atlas Shrugged said the "only power is the power to crack down on criminals". The problem with governmental discretion and vaguely worded and inaccessible laws that seem to breed new variants like rabbits is that we are all guilty of something at some point because we violated a rule of which we were likely not even aware. The USSR's Chekist secret police as well as China utilize laws like "a crime against the state" where they invent what is a violation to fit their desire to arrest, harass, intimidate and imprison someone. This is an absolute violation of the Rule of Law but we are headed in that direction.

1. Interest group politics

2. Rent seeking

3. Regulatory capture

4. Elites \& Masses

5. Institutions matter

Mancur Olsen, The Logic of Collective Action (1965) and Olsen, The Rise and Decline of Nations (1982).

- Corrective tax on externality. Smaller, well-organized interest groups can benefit at the expense of the majority.

\footnotetext{
${ }^{14}$ E-Mail, Randall Holcombe to David Barnhizer, January 13, 2016.
} 
Rent Seeking: In which an economic actor seeks to obtain profit without providing productive benefit to others. ${ }^{15}$

1. Gordon Tullock, "The Welfare Costs of Tariffs, Monopolies and Theft" (Western Economic Journal 1967).

2. Anne Krueger, "The Political Economy of the Rent-Seeking Society", American Economic Review 1974. The idea of privately profitable things that don't add anything to the productivity of a nation.

3. Tullock, "The Transitional Gains Trap", Bell J. of Economics (1975).

\section{Rent Extraction:}

1. Fred McChesney, "Rent Extraction and Rent Creation", J. of Legal Studies (1987).

2. Peter Schweizer, Extortion (2013).

3. Regulatory Capture, George Stigler, "Theory of Economic Regulation", Bell J. of Economics and Management Science (1971). The way government actually works.

Elite Theory-Elites and Masses:

1. Arthur Bentley

2. David Truman

3. C. Wright Mills, The Power Elite

4. Joseph Hacker and Paul Pierson, Winner Take All

5. Martin Gilens, Affluence and Influence

Institutions Matter:

1. W. Baumol, Entrepreneurship

2. Hernando de Soto, The Other Path

3. Douglas North, Institutions and Institutional Change

4. Daron Acemoghe, Simon Johnson and Robinson, "Colonial Origins of Comparative Development", American Economic Review (2001)

Cronyism:

1. J. Stiglitz, The Price of Inequality

2. D. Stockman, The Great Deformation

3. Ralph Nader, Unstoppable (2014)

4. Peter Schweizer, Extortion

Controlling Cronyism:

1. Government is the Problem, what is the solution?

15 “The Political Economy of the Rent-Seeking Society." American Economic Review 64 (1974): 291-303. Tullock, Gordon. 
2. More regulation, more regulation, more government programs, more government oversight?

3. OR less government?

Cronyism and Favoritism override the Rule of Law:

1. Do we have a market economy and Rule of Law, or crony capitalism?

2. Regime uncertainty exists where cronyism replaces the Rule of Law.

3. How do we control cronyism?

- Cronyism is a symptom of a problem. Holcombe says the problem is big government.

- We need to control cronyism and discretion through the Rule of Law.

\section{The Rule of Law as a Fragile and Ephemeral Ideal}

Ernest Becker warned about the ephemeral nature of human reality in words that are fully applicable to the integrity and preservation of the Rule of Law and socially-oriented economics. Becker warns: "The world of human aspiration is largely fictitious and if we do not understand this we understand nothing about man.... Man's freedom is a fabricated freedom, and he pays the price for it. He must at all times defend the utter fragility of his delicately constituted fiction, deny its artificiality." 16 John Locke and others have described the important role of the legal system as umpire. ${ }^{17}$

George Gilder once wrote: "Idealists ... always much abominate what they call hypocrisy. But hypocrisy-the insincere expression of unfulfilled ideals-is the means by which the influence of ideals is extended beyond the small circle of true believers." 18 Not only are we enmeshed in a cultural context that is an artificial system, it is vital that we pretend that it is something more lest it disintegrate around us and we subside to a system akin to Hobbes's "state of nature". In that regard we would be wise to pay attention to the fact that humans are not essentially "good" and that we are increasingly devolving into a condition of hyper-factionalism and strategies by interest groups that separate rather than bring us together in a community with shared aims and values.

Our problem is that conflict and disputes over comparative individual worth and principle are inevitable in any context within which humans function. Thomas Hobbes tells us: "men have no pleasure, (but on the contrary a great deale of griefe) in keeping company, where there is no power able to over-awe them all. For every man looketh that his companion should value him, at the same rate he sets upon himselfe: .... Hereby it is manifest, that during the time men live without a common Power to keep them all in awe, they are in that

\footnotetext{
16 ERNEST BECKER, THE BIRTH AND DEATH OF MEANING 139 (2d ed. 1971).

17 See, John Locke, Of Civil Government Second Treatise, at 67,68. This was further developed in David Barnhizer, "The Virtue of Ordered Conflict: A Defense of the Adversary System", 79 Nebraska Law Review 657 (2000).

18 GEORGE GILDER, WEALTH AND POVERTY, at 107 (Bantam ed. 1982).
} 
condition which is called Warre; and such a warre, as is of every man, against every man." 19

Thomas Green once wrote, "Every mind is fettered at some point, ridden with presuppositions and stereotypes that stand in the way of mental freedom." He adds: "we tend to order our [core] beliefs in little clusters encrusted about ... with a protective shield that prevents any cross-fertilization among them or any confrontation between them." 20 The reality threatening the commitment to liberty and individual rights is that on one hand we are increasingly ignorant while on the other deathly afraid of the numerous troubling and complex conditions of our society. One result is that we are running from freedom and personal responsibility while seeking to submerge ourselves within a larger social order that provides us with structure, a false kind of certainty and a sense of security. This allows us to avoid personal responsibility and stifles individual growth and development of the kind we thought resided at the core of the American ethos.

In terms that help to understand the problem this creates for the Rule of Law, Daniel Boorstin concluded that: "The discovery, or even the belief that man could make his own laws, was burdensome.... [N] early every man knew in his own heart the vagueness of his own knowledge and the uncertainty of his own wisdom about his society. Scrupulous men were troubled to think that their society was governed by a wisdom no greater than their own." 21 Boorstin went on to describe our quandary. "[T]he mystery-of law in modern society ... [is] how retain any belief in the immanence of law, in its superiority to our individual, temporary needs, after we have adopted a whole-hearted modern belief in its instrumentality? How continue to believe that something about our law is changeless after we have discovered that it may be infinitely plastic? How believe that in some sense the basic laws of society are given us by God, after we have become convinced that we have given them to ourselves." 22

Boorstin's analysis highlights our dilemmas about how to understand the place of law in American society. It also helps our awareness about the importance of the Rule of Law as a "deep" creed that operates as a check on the creation and interpretation of specific laws and legal institutions functioning as instrumentalities of specific political choices aimed at achieving specific political goals. His insights are helpful in determining the ways and limits of how we use law as a technique for achieving goals. This includes the tradeoffs that are required between our desires to achieve goals and the potential damage inherent in trying to do so too rapidly. This also applies to the relationships between the goals of social action and law, including the connection between law and the operation of our economic system as a means of creating wealth and opportunity.

\section{The Rule of Law and the Growth of an Incommensurable Rigidity}

\footnotetext{
19 HOBBES, THE LEVIATHAN.

20 Thomas Green, The Activities of Teaching 51 and 47 (1971).

21 DANIEL BOORSTIN, THE DECLINE OF RADICALISM 74 (1963).

22 DANIEL BOORSTIN THE DECLINE OF RADICALISM 76 (1969).
} 
John Finnis has suggested law is a "cultural object, constructed or posited by creative human decision ... an instrument we adopt because we have no other way of agreeing amongst ourselves over significant spans of time about precisely how to pursue our moral project well." 23 Finnis describes law as providing "algorithm[s] for deciding as many questions as possible.... As far as it can, the law seeks to provide sources of reasoningstatutes and statute-based rules, common law rules, and customs-capable of ranking (commensurating) alternative dispute resolutions as right or wrong, and thus better or worse." 24

One problem is that some matters are not commensurable and, even if they were in an abstract sense in a political system that has devolved into "hyper-factionalism", the only thing that matters from a specific special-interest faction's point of view is whether its desired goals have been achieved. Evidence, logic and proof are irrelevant because outcome is the only real test for competing factions. What is going on in American society is a series of increasingly non-negotiable contests for the allocation of social goods and responsibilities, preferred opportunities, power and status. This can be seen in the neverending story of inequality and merit in a political society and the conflicts over the criteria to be utilized in allocations.

One area in which non-negotiable beliefs dominate is involves perspectives on merit, inequality and the opportunity to acquire social goods. As John Gardner explains: "We might as well admit that it is not easy for us as believers in democracy to dwell on the differences in capacity between men. Democratic philosophy has tended to ignore such differences where possible, and to belittle them where it could not ignore them.... But extreme equalitarianism-or as I would prefer to say, equalitarianism wrongly conceived-which ignores differences in native capacity and achievement, has (17) not served democracy well. Carried far enough, it means the lopping off of any heads which come above dead level. It means committee rule, the individual smothered by the group. And it means the end of that striving for excellence which has produced mankind's greatest achievements." 25

In his masterful work Propaganda, Jacques Ellul reminds us of the enormous and growing gap between ideals and philosophical awareness versus the faction-produced stereotypes and superficiality of modern society where far too many people hide behind ignorance and commitment to movements that provide "easy answers". Ellul writes: "A stereotype is a seeming value judgment, acquired by belonging to a group, without any intellectual labor.... The stereotype arises from feelings one has for one's own group, or against the "out-group." Man attaches himself passionately to the values represented by his group and rejects the cliches of the out-groups.... The stereotype ... helps man to avoid thinking, to take a personal position, to form his own opinion." 26

\footnotetext{
23 J. Finnis, "Natural Law and Legal Reasoning”, 38 Cleve. St. L. Rev. 1, 6 (1990). See generally, J. FINNIS, NATURAL LAW AND NATURAL RIGHTS (1980).

24 J. Finnis, id.

25 John W. Gardner, Excellence: Can We Be Equal and Excellent Too? 17, 18 (Harper \& Row, N.Y. 1961).

${ }^{26}$ Jacques Ellul, Propaganda
} 


\section{The "Truth" of the Rule of Law}

Lord Acton observed that: "All power corrupts and absolute power corrupts absolutely." The fuller context is useful for understanding this idea. Acton stated: "Liberty is not a means to a higher political end. It is itself the highest political end ... liberty is the only object which benefits all alike, and provokes no sincere opposition ... The danger is not that a particular class is unfit to govern. Every class is unfit to govern [emphasis added] ... Power tends to corrupt, and absolute power corrupts absolutely." ${ }^{27}$ No group can resist the tendency to abuse power and so we must better respect the need for a balance of power and its diffusion across political interests.

Aristotle offered an important insight in his observation that "the law has no power to command obedience except that of habit, which can only be given by time, so that a readiness to change from old to new laws enfeebles the power of the law". ${ }^{28} \mathrm{He}$ warned that law is a fragile phenomenon and that its creators, interpreters and appliers need to take that potentially ephemeral nature into account. The problem we face is that over the past several generations we have seen a still-intensifying rise in factionalism, interest group politics, special interests and their strategic social agendas seeking to use the power of instrumentalist law to achieve their defensive and offensive goals in which they pursue not only power and goods for themselves but extract power and goods from others they feel have gained their shares unfairly or simply possess something a group wants for its own members.

Control of legal and political institutions that create, modify and enforce legal rules provides the battleground in this period of hyper-factionalism. Law is a central element in the struggle between interest groups because as Lawrence Friedman concluded in American Law: "in complex societies custom is far too flabby to do all the work-to run the machinery of order. Law carries a powerful stick: the threat of force. This is the fist inside the velvet glove...." 29

\section{The Will of the Political Mass and the Re-Engineering of Individuals}

Even though some of us treasure individualism being true to that aim is far more difficult than might be imagined. One reason is the power of our institutions and groups in terms of their ability to set our agendas, and provide rewards for behavior desired by the group to which we pledge allegiance and punish behavior that contradicts or otherwise disserves the group's aims and beliefs. Peter Berger sets out a fundamental problem relative to the tension between individual liberty and the power of groups and factions both public and private. "One moves within society within carefully defined systems of power and prestige. And once one knows how to locate oneself, one also knows that there is not an awful lot that one can do about this." 30

\footnotetext{
27 From Great Thinkers on Liberty, "Lord Acton's epic warning that power corrupts, and absolute power corrupts absolutely," http://www.libertystory.net/LSTHINKACTON.html.

${ }^{28}$ See, Aristotle, The Politics, Bk. II, c. 8. B. Jowett trans., The Oxford Translation of Aristotle, W.D. Ross ed. (1921)

29 Lawrence Friedman, American Law 257.

30 Peter Berger, Invitation to Sociology 66 (1963).
} 
According to Roscoe Pound, the purpose of the legal order: "is to secure as much as may be of the whole scheme of interests, that is of the whole scheme of men's desires or demands involved in living together in civilized society, with the least friction and waste." 31 Kamenka and Tay argue that: "The law ... is made to make man, to change him, to strengthen one side of his constitution, behaviour and activities against others." 32 In the context of the struggle of the liberty of the individual against the majority this means that the majority feels entitled to use the law as an instrumentalist mechanism to achieve social engineering through authoritative rules that mold the individual into a form considered appropriate to the beliefs and desires of the majority or even more commonly, the agendas of a well-organized minority that has seized the levers of law and social control.

Disputes over the priority and weight to be given different kinds of arguably meritorious qualities are found even in simple democracies. Few will agree on the terms of distributive justice or on the specific choices of merit that should govern us. Aristotle describes the disputes over who should be considered best and most virtuous. "[T] he definitions on the basis of which people claim that they themselves deserve to rule while everyone else deserves to be their subjects, are none of them correct. For, in fact, even against those whose claim to deserve control of the ruling body is based on virtue, multitudes would have some argument of justice to make, as they would likewise against those whose claim to deserve it is based on wealth." [Collective action?] The problem is that: "The universal and chief cause of ... revolutionary feeling [is] ... the desire of equality, when men think they are equal to others who have more than themselves or, again the desire of inequality and superiority, when conceiving themselves to [be] the superior they think they have not more but the same or less than their inferiors." 33

\section{Institutions, Orthodoxies and Organizations}

Robert Dahl explains: "Organizations ... are not mere relay stations that receive and send signals from their members about their interests. Organizations amplify the signals and generate new ones. Often they sharpen particularistic demands at the expense of broader needs, and short-run against long-run needs. Leaders therefore play down potential cleavages and conflicts among their own members and exaggerate the salience of conflicts with outsiders. Organizations thereby strengthen both solidarity and division, cohesion and conflict; they reinforce solidarity among members and conflicts with nonmembers. Because associations help to fragment the concerns of citizens, interests that many citizens might share-latent ones perhaps-may be slighted." 34

Dahl goes on to describe the means by which the primary organizations to which we pledge allegiance shape us and control our relationships and perceptions. He explains: "[B]y emphasizing aspects of the self that are enhanced by organizational or segmental gains,

\footnotetext{
31 Roscoe Pound, New Paths of the Law 3 (1950).

32 E. Kamenka and A.E.S. Tay, Law and Social Control viii (1980).

33 THE POLITICS, supra n. 2, Bk. V, c. 2. See the discussion of claims to entitlement to rule others in the POLITICS, Bk. 3, c. $13,1283 \mathrm{~b} 27$.

34 Robert A. Dahl, Dilemmas of Pluralist Democracy: Autonomy vs. Control 44 (Yale University Press 1982).
} 
organizational pluralism helps to produce in political actors a set of perceptions and beliefs, even a persistent political culture, in which the absence of a common, public, or widely shared set of interests is a self-fulfilling prophecy. I and my "interests" become attached to my social segment and my organizations; leaders in my organizations in turn seek to increase the strength and salience of my attachments; my public interest becomes identical in my mind with my segmental interest; since what is true of me is true of others, we all passively or actively support the organizational fight on behalf of our particular interests; finally, as levels of distrust rise and effective communication (44) declines, the "rational" pursuit by each of us of our particularistic self-interest may lead to mutually damaging outcomes." 35 This has significant implications for not only the Rule of Law but for the probability of collaborative collective action on important social issues.

\section{Liberal Democracy v. Cultural Democracy}

John Fonte offers an insightful discussion of the dynamics of the distinction between liberal democracy and cultural democracy. He explains: "In contrast to the philosophy of liberal democracy, which promotes equality of opportunity for individuals irrespective of race, ethnicity, and sex, the ideology of cultural democracy defines justice as achieving a particular result: proportional representation of cultural minorities and women in all sectors of society." 36 He adds: "To be sure, liberal democrats also oppose racism and sexism, but they define these terms differently and consequently propose different solutions to the problems resulting from bigotry. Traditionally liberal democrats reject racial and sexual prejudice that prevents individuals from achieving the same goals that other individuals are entitled to achieve. The U.S. Civil Rights Act of 1964 in its original form is a classic example of liberal-democratic thinking, whereas subsequent judicial and bureaucratic interpretations of the bill that established group rights represent culturaldemocratic thinking." 37

Fonte warns: "The challenge to the "liberal" half of liberal democracy -- individual rights, equality of individual citizenship, freedom of expression, and a private sphere free from political interference -- is more explicit and direct than the challenge to popular sovereignty and majority rule. Not only do important segments of the Western elite in education, government, and law question the traditional principles of liberalism; they essentially advocate an alternative world view: cultural democracy." 38

Max Lerner writes in connection with Mill's On Liberty: "Mill was a pioneer in seeing, with the growth of social egalitarianism and mass culture, the shadow of "an oppressive yoke of uniformity in opinion and practice." 39 Lerner prefaces Mill's On Liberty with the observation that: "The great strength of the book lies in its moving away from a narrow view of human freedom as an immunity from the power of the state. Mill takes two giant steps away from this, toward a broader view of freedom. One step is to see that the

\footnotetext{
35 Dahl, Pluralist Democracy, id, at 45.

36 John Fonte, "Upstream," National Review, February 6, 1995.

37 John Fonte, "Upstream," National Review, February 6, 1995.

38 John Fonte, "Upstream," National Review, February 6, 1995.

39 Lerner, Mill's Essential Works, 250
} 
enemies of human freedom may be found in the attitudes of the people themselves, and that the tyranny of the majority may be as hostile to the expression of a man's life and temperament as the tyranny of the state. He saw history as a kind of circulation of creeds, each of which demanded acceptance from the individual: no sooner is one swept away, then another starts forming, and-after a period of transition in which the latitude for opinions is relatively great-the new one is established and solidified, and exercises the same "power of compression" as the other." 40

\section{The Power Pluralism of Single-Cause, Single-Interest Groups}

Jacques Ellul wrote in The Technological Society: "The man of today is no longer able to understand his neighbor because his profession is his whole life, and the technical specialization of this life has caused him to live in a closed universe." 41 In Propaganda, Ellul goes on to remind us: "A stereotype is a seeming value judgment, acquired by belonging to a group, without any intellectual labor.... The stereotype arises from feelings one has for one's own group, or against the "out-group." Man attaches himself passionately to the values represented by his group and rejects the cliches of the out-groups.... The stereotype, ... helps man to avoid thinking, to take a personal position, to form his own opinion."

Peter Drucker offers: "The new pluralism ... focuses on power. It is a pluralism of singlecause, single-interest groups-the "mass movements" of small but highly disciplined minorities. Each of them tries to obtain through power what it could not obtain through numbers or through persuasion. Each is exclusively political." 42 Drucker suggests: "If history is any guide, it will take a century or so before we have legal or political doctrine appropriate to the realities of the new pluralism. But we cannot wait until the philosophers explain theoretically what has happened. Politicians, law courts, businessmen, executives of the new organizations have to act." ${ }^{43}$ The issues to be addressed include social, political, and community responsibility balanced against or synthesized with an individual's rights and responsibilities, and the role, functions and limits of government in a pluralist society.

Robert Wolff warns: "[I]n matters of collective social action concerning moral and political issues, the freest possible expression of competing views does seem called for. Even before we have reasoned out the principles underlying the right ordering of the political community, our instincts tell us that our society is diminished by the arbitrary stifling of the views of dissenting parties. Experience suggests that a vigorous competition of opposed policies, however disruptive of social tranquillity [sic], is to be preferred to the enforced quiet of political repression." ${ }^{44} \mathrm{He}$ adds: "But it is not to assist the advance of knowledge that free debate is needed. Rather, it is in order to guarantee that every legitimate interest shall make itself known and felt in the political process. Every party to the decisions of government-which is to say, every citizen-must have the opportunity to

\footnotetext{
40 Essential Works of John Stuart Mill 250 Max Lerner ed., (Bantam 1961).

41 TECHNOLOGICAL SOCIETY at 132.

42 Peter Drucker, The New Realities 76 (Harper \& Row 1989).

43 Drucker, New Realities 86.

${ }^{44}$ Wolff 17
} 
argue his case and bring his pressure to bear. A voice silenced is a grievance unredressed or an interest denied a measure of satisfaction. Justice, not truth, is the ideal served by liberty of speech." 45

In his book, Power, Adolf Berle captured the reality of social movements and their quest for institutional control. The recognition that power requires control of decision-making institutions and the ability to set and enforce rules that serve your interests has created a competition to occupy the sources of power and define the rules of decision to ensure that particular interest group preferences are reflected in the institutional choices. Berle warned that control of institutions is the only way by which people can extend their power beyond the limited reach of their fists or guns.

For previously subordinated groups this is particularly important because those they are seeking to supplant tend to possess greater power and the only effective strategy in a Rule of Law system has been to capture the mechanisms by which law is created, interpreted, applied and enforced. Obviously, this means that those seeking to capture the ability to dictate rules to others or to protect against others' control over their interests must implement effective strategies to gain possession of the institutions that make and enforce the rules or laws. ${ }^{46}$ Once this is done, creating linguistic behaviors that are defined as violating the new rules relating to treatment of your protected class becomes an important element of control and intimidation.

The conflicts produced by the tensions of free speech and free thought doctrines that promote the introduction of controversial positions in the face of dominant or quasifanatical interests are supposedly designed into our political system. ${ }^{47}$ Madison captured this in his description of the inevitability of factions in America's democracy. ${ }^{48}$ The idea is that free speech serves to protect and enrich the social community. This presumably occurs through the education of participants, and the venting of potentially explosive internal hostilities. [contrary/cartoons as to Islam and Sikhs counters the assumption] The fear behind this assumption is that if conflicted discourse is repressed it builds up into unresolved conflicts that weaken the spirit of the democratic system. ${ }^{49}$ Other purposes thought to benefit the political community include attaining a degree of truth through free and open discourse, and increasing the willingness to develop social compromises through

\footnotetext{
45 Robert Paul Wolff, The Poverty of Liberalism 18 (Beacon Press, Boston 1968).

46 Adolf A. Berle, Power at 92 (1967).

47 The assumption that reasoned discourse can be achieved in regard to any issue of intense social concern may unfortunately represent an impossible dream. Jung warns: "Rational argument can be conducted with some prospect of success only so long as the emotionality of a given situation does not exceed a certain critical degree. If the affective temperature rises above this level, the possibility of reason's having any effect ceases and its place is taken by slogans and chimerical wish-fantasies." C.G. Jung, The Undiscovered Self 12, 13, translated from the German by R.F.C. Hull (Mentor 1957).

48 James Madison, Federalist \# 10.

49 These are of course all unproven assumptions about what will occur if speech is allowed broadly, and they are assumptions that fit into a particular cultural context and philosophical worldview. Each of these assumptions, in fact, may be disputed as invalid as how we actually function although I admit I prefer them to other more dismal articulations.
} 
the exchange of positions and reasons for actions. ${ }^{50}$ [cultures who are convinced they already know the truth/revealed, and therefore are not open to discourse or to having their "truth" questioned]

Apart from the social justifications of free speech the ideal is also intended to provide important indirect benefits at the level of the individual. Its function here is aimed more at facilitating individual development. The presumed social benefits are more indirect, i.e., the principle being that a society comprised of "developed" humans is a qualitatively richer society. This advances the idea represented by Aristotle's idea of eudaimonia, or human flourishing, in which a primary function of the State was to create conditions conducive to the maximum qualitative development of individual humans. The understanding was that a community of the most progressive individuals attaining their maximized potential as humans would automatically be the best community. ${ }^{51}$ This is reflected in the words of Justice Brandeis, concurring in Whitney v. California:

Those who won our independence believed that the final end of the State was to make men free to develop their faculties; and that in its government the deliberative forces should prevail over the arbitrary. They valued liberty both as an end and as a means. They believed liberty to be the secret of happiness and courage to be the secret of liberty. They believed that freedom to think as you will and to speak as you think are means indispensable to the discovery and spread of political truth; that without free speech and assembly discussion would be futile....52

\footnotetext{
${ }^{50}$ Part of the "rational discourse as the core of democracy" argument is obviously flawed. It is impossible to have fully rational discourse in a complex community. Emotions, ignorance, bias and self-interest all erect barriers to discourse and they are barriers we seldom if ever transcend in any matter of weight. Our dilemma is even more intractable than that of conscious duplicity and understood biases because at least we are intellectually aware of what we are doing. The factor that makes it impossible to have real discourse relating to issues of core social behavior is that the deep value systems upon which our individual systems of ultimate truths are grounded are not rational or even necessarily consistent with other clusters of belief containing potentially competing deep-values. Thomas Green warns that we hold within us multiple and frequently inconsistent value systems and beliefs. We hold our value systems-not as an integrated and seamless whole but in independent clusters that operate according to their own set of rules and assumptions. This allows the holding of incompatible beliefs and the individual systems are resistant to being "infected" by fact and evidence of a kind not compatible with the rules of individual systems. Thomas Green, The Activities of Teaching 43 (1971).

51 See, Aristotle, Nichomachean Ethics, c. VII, Bk. I, for his description of eudaimonia or human flourishing. One scholar sums it up as: “Aristotle teaches that each man's life has a purpose and that the function of one's life is to attain that purpose. He explains that the purpose of life is earthly happiness or flourishing that can be achieved via reason and the acquisition of virtue. Articulating an explicit and clear understanding of the end toward which a person's life aims, Aristotle states that each human being should use his abilities to their fullest potential and should obtain happiness and enjoyment through the exercise of his realized capacities. He contends that human achievements are animated by purpose and autonomy and that people should take pride in being excellent at what they do. According to Aristotle, human beings have a natural desire and capacity to know and understand the truth, to pursue moral excellence, and to instantiate their ideals in the world through action." See, Edward W. Younkins, "Aristotle: Ayn Rand's Acknowledged Teacher," The Autonomist, http://usabig.com/autonomist/articles/aristotle.html. 8/24/05.

52 Whitney v. California, 274 U.S. 357 (1927).
} 
As admirable as Justice Brandeis's words might be, they compel us to confront the core of our dilemma. Ours is now - and perhaps if we are honest we should admit it always has been - a culture in which positions are too often taken and held to rigidly regardless of evidence. Critics are attacked with contempt and propaganda. ${ }^{53}$ This occurs in many venues. ${ }^{54}$ As the examples described in the next section indicate, we have a wide variety of techniques by which we repress speech. Limitations of discourse by secular and religious sources is therefore not new. But, even if the ideal of honest discourse has too often been honored in the breach, the intensity and scale of speech repression has grown. ${ }^{55}$

The European history of speech inhibition differs from the American experience. The monarchical systems that characterized the European nations through the early twentieth century produced a legal environment in which it was dangerous and potentially fatal to criticize government. Leviathan brooks little or no dissent and doctrines such as seditious libel and constructive treason were fashioned to inhibit criticism. ${ }^{56}$ Criticizing government

\footnotetext{
53 Consider, for example, the unfortunate episode involving Harvard President Lawrence Summers' comments on possible differences in scientific ability. For weeks afterward there were numerous and well-organized calls for his firing. It is only fair to review the entire presentation before lynching Summers. He subsequently apologized if he offended anyone. See, "Remarks at NBER Conference on Diversifying the Science \& Engineering Workforce," Lawrence H. Summers, Cambridge, Mass., January 14, 2005. A telling critique of such criticisms is found in Charles Murray, "The Inequality Taboo," Commentary, September 2005, http://www.commentarymagazine.com/article.asp?aid=12002015 1 (visited 9/5/05).

${ }^{54}$ James Madison recognized the need to balance competing interests in his analysis of factious groups. In Federalist No. 10, Madison sets out the idea of faction in the following words. "By a faction I understand a number of citizens, whether amounting to a majority or minority of the whole, who are united and actuated by some common impulse of passion, or of interest, adverse to the rights of other citizens, or to the permanent and aggregate interests of the community." Federalist \# 10 (November 22, 1787) The Federalist, Edited and introduced by Jacob E. Cooke (1961), at 56. Madison goes on to describe two "cures" for faction. One is to "destroy the liberty" that allows it to bloom, the other is to give "to every citizen the same opinions, the same passions, and the same interests." Federalist \# 10, id, at 58. See also Thurman W. Arnold, The Folklore of Capitalism 9-10 (1967):

The creeds of these countries [the United States, Germany, Russia, and Italy], of course, do not describe or explain the events taking place there. ... The lessons of history are used in the same way. Men do not actually search history to avoid the mistakes of the past. They seek convenient analogies to show the dangers in failing to adopt the creed which they advocate. The legal or economic prophet of today sincerely believes that he is using a process of analysis and reason to help the thinking man in a voluntary choice of a political or economic creed.
}

But how do men actually choose these creeds? The answer is that they do not choose them. Men become bound by loyalties and enthusiasms to existing organizations. If they are successful in obtaining prestige and security from these organizations, they come to regard them as the ultimate in spiritual and moral perfection. This attitude is necessary for the morale of these institutions.

55 On this theme see, Diane Ravitch, The Language Police: How Pressure Groups Restrict What Students Learn (New York, Alfred A. Knopf 2003); and David E. Bernstein, You Can't Say That!: The Growing Threat to Civil Liberties from Antidiscrimination Laws (Washington, Cato Institute 2003). See also, Dawn C. Nunziato, “The Death of the Public Forum in Cyberspace," 20 Berkeley Technology L. J. 1115 (2005).

56 See, De Libellis Famosis [(1606) 5 Co. Rep. 125a.] in which seditious libel against the King or a powerful private person could be punished because the person might seek revenge for the insult resulting in a breach of the peace and if against a governmental official could undermine the relationship between citizen and government. See, "Consultation Paper on the Crime of Libel,” The Law Reform Commission, Dublin, Ireland 1991,

http://www.lawreform.ie/publications/data/volume10/lrc 65.html (8/24/05). It was said: "The rules in the Star Chamber developed differently from those in the common law courts. For example, it was sufficient if the libel were published to the victim only; neither did it matter whether the victim was alive or dead. Of extreme importance is the rule that truth was not a defence; indeed the contrary principle was expressed in the well-known phrase-“The greater the truth, the greater the libel.” The often-cited example given to explain this is provided by Hudson-"for, as the woman said, she would never grieve to have been told of her red nose if she had not one indeed."11 A true libel was therefore a "greater" one because of its greater potential to provoke a breach of the peace. This merely reinforces the obvious fact that the developing criminal offence of libel had little to 
in England was in fact considered even more problematic if the criticisms were true than if false for the simple reason that true criticisms could not be effectively disputed and the integrity of government (or the Crown) was therefore undermined. ${ }^{57}$ Although the rules have changed, European discourse still labors under this long history of restrictions and punishment of speech. ${ }^{58}$

do with reputation and much more to do with maintenance of the public peace.”

57 It is fascinating that the doctrines relating to speech suppression and punishment have to deal with technology. The system of the Star Chamber was created independent of the Common Law courts apparently in response to the heightened capability of mass printing and the ability to spread criticism more widely than by simple rumor and word of mouth. See, "Consultation Paper on the Crime of Libel,” The Law Reform Commission, Dublin, Ireland 1991,

http://www.lawreform.ie/publications/data/volume10/lrc_65.html (8/24/05), where it is stated that: "In 1476, Caxton set up the first printing press at Westminster and in 1488, the Star Chamber was set up in order to monitor and suppress criticism of Church and State, which were at that which were at that time closely interwoven. The primary libels with which it was concerned were therefore libels of a seditious or blasphemous nature. However, the Star Chamber also wished to suppress duelling, which was the fashionable means of vindicating attacks upon honour or reputation, and to this end it also punished defamatory libels i.e. libels which impugned the integrity a private individual. In 1606, the Star Chamber held in the celebrated case of De Libellis Famosis [(1606) 5 Co. Rep. 125a.] that it was an offence to defame the deceased Archbishop of Canterbury. The nature of the tasks of the Star Chamber and common law courts were therefore altogether different; while the Star Chamber was attempting to discourage matter which either threatened state security or might cause a breach of the peace, the common law courts were concerned with rectification of damage done to the reputation of an individual.”

58 Constructive treason involved the offense of criticizing the Crown, speaking in favor of the King's death or aiding his enemies. Nor should we conclude the doctrine of seditious libel has been abandoned. See, e.g., the opinions of Taschereau, J. and other jurists in Boucher v. R., (Supreme Court of Canada), [1951] S.C.R. 265, where on appeal Taschereau, J. observed: "At the first hearing of this appeal, the Court did not agree as to the ingredients that are necessary to constitute the offence of seditious libel. Upon application, a new hearing was granted and heard by the full Court, and in view of the opinions now expressed by the majority, it is settled I think that generally speaking, the writings complained of must, in addition to being calculated to promote feelings of ill-will and hostility between different classes of His Majesty's subjects, be intended to produce disturbance of or resistance to the lawfully constituted authority. "

[Taschereau continued] "But as pointed out by my brother Cartwright, there is another definition of seditious intention which I think, must be accepted. I agree with him that an intention to bring the administration of justice into hatred or contempt or to excite disaffection against it, is a seditious intention. In the present case, there is I think sufficient evidence upon which a properly instructed jury could find that there was a seditious intention." 